\title{
What Did They Take Away?: Examining Newly Qualified U.S. Teachers' Visions of Learning and Teaching Science in K-8 Classrooms
}

\section{ABSTRACT}

This study investigated newly qualified K-8 teachers' visions of science learning and teaching after they had completed preparation in a science teaching methods course I taught. What visions of science learning and teaching were these newly qualified teachers taking away from my course? How did these visions compare with those advocated by reform documents? I examined their class work and interviewed them after the course to document their ideas about science learning and teaching as they were about to begin their first year of teaching. Other data sources included participants' assignments, weekly reflections, and multi-media portfolio finals. Semi-structured interviews provided the emic voice of participants, after graduation but before they began to teach. Four strands of science proficiency articulated in a U.S. reform document provided a framework for interpreting activities, assignments, and interview responses. Some participants intentionally incorporated and implemented reform-based strategies in field placements in $\mathrm{K}-8$ classrooms during the methods course and student teaching. The strands of scientific proficiency were evident in activities, assignments and participants' interviews in varying degrees.

\section{KEYWORDS}

pre-service, elementary science, methods, strands of science proficiency, practitioner research

The purpose of this study was to examine key ideas and understandings pre-service K-8 teachers used to envision the teaching of science after completing my science teaching methods course, but prior to entering the teaching profession. In other words, how did they envision themselves as teachers of science as they were about to begin teaching? In addition, how did the visions they expressed align with recommendations for science teaching and learning articulated in U.S. science education reform documents?

Like participants in methods courses I had taught previously, these pre-service teachers were soon commenting that science was not being taught in the elementary schools where they were completing their student teaching experiences. They complained that it was a struggle for them to be able to observe, and, in some cases, to teach a science 
lesson. My question became, if the pre-service teachers were not seeing much science being taught, and if they were finding it a challenge to carve out time to include science lessons in their teaching experiences, then what would they remember and how would they envision the teaching of science after they had completed my course? Would their visions for teaching science in their own classrooms include the reform-based ideas and concepts implemented in each of my class sessions?

There is a substantial body of knowledge about pre-service teacher beliefs during their course work (Jones \& Carter, 2007; Kaufman \& Moss, 2010; Luft, Roehrig, \& Patterson, 2003; Richardson, 2003). However, there is little research about the transition from student to teacher, because as Luft (2007) points out there is a dearth of appropriate transition programs for new teachers. A small handful of studies (Adams \& Krockover, 1997; Simmons, et al, 1999) have specifically looked at connections between secondary science teacher preparation program experiences and new teacher enactment in the classroom. Additionally, there is much research about new teacher beliefs (Kaufman \& Moss, 2010; Luft, Roehrig \& Patterson, 2003) and ways those beliefs play out during induction years. I was unable to find any research specific to newly qualified teachers, after graduation, but before they begin teaching. This study contributes to the literature about visions of science teaching held by one group of such newly qualified teachers.

\section{WAYS TO DESCRIBE TEACHERS' IDEAS ABOUT LEARNING AND TEACHING}

Various terms have been used to refer to ways in which teachers think about learning and teaching, such as beliefs, attitudes, mental models, views, perceptions, and intentions. For example, Luft and Roehrig (2007) gave a detailed description of science teacher beliefs, noting there are many differing ideas in what the term beliefs means to different researchers. McGinnis, Parker, and Graeber (2004) referred to both attitudes and beliefs; whereas, Thomas, Pedersen, and Finson (2001) discussed teachers' mental models and beliefs. Morrison, Raab, and Ingram (2009) used the term views to describe the ideas that teachers have about the nature of science. Some refer to teachers' perceptions (Lederman, 1999), while others refer to teachers' intentions (Haney, Czerniak, \& Lumpe, 1996).

The term vision appears in many discussions of teacher identities. Abell (2005), for example, found that during a course in science teaching methods, prospective teachers were "building their views of inquiry and their visions of themselves as future teachers" (p. 287). In a study about implementing a reflective orientation toward the teaching and learning of science, Abell \& Bryan (1997) asked prospective teachers to reflect on their science experiences so they could look at their own histories and then to the future to envision themselves as science teachers.

In a review of science teacher education literature, Davis, Petish, and Smithey (2006) found that teachers who were better able to envision themselves as science teachers gained more from their education program and became better inquiry-based science teachers. According to the authors, "envisioning oneself as a science teacher is critical in becoming a professional” (p. 31). Davis (2006) found that expert teachers demonstrated a more complex view of teaching than pre-service teachers, in part because they made more connections in teaching and were more analytical about teaching and learning in the classroom. Davis described this as professional vision, and stated that developing professional vision is important in enacting effective instruction. 
Sherin and Han (2004) shared this view of a "professional vision," emphasizing the importance of developing such a view in making instruction more effective. She proposed that pre-service teachers can learn ways to use this "professional vision" as they are teaching. However, it may be unreasonable to expect pre-service teachers to do so effectively at the beginning of their teaching careers (Davis, 2006). Anderson, Smith and Peasley (2000) pointed out that beginning (including pre-service) teachers may be over-taxed by reflection-in-action because they are new to many of the tasks of teaching. This raises the question of whether newly-qualified teachers who are not yet teaching are able to analyze and make connections to teaching in ways that will inform their future classrooms.

In this study, the term vision has a dynamic and active connotation. Vision is what we hope to achieve, what we think might be possible; a goal to reach for. It acknowledges we are here now in the present, but looking toward the future, in this case, the future of science teaching and learning. By asking pre-service teachers to begin to analyze and make connections to their future teaching, I attempted to have them envision the possibilities of their new teaching assignments in ways that could inform their future practices.

\section{U.S. SCIENCE EDUCATION REFORM DOCUMENTS}

The U.S. National Science Education Standards (NRC, 1996) recommended that teachers implement an inquiry-based program. This approach engages students in doing what scientists do:

asking questions, planning and conducting investigations, using appropriate tools and techniques to gather data, thinking critically and logically about relationships between evidence and explanations, constructing and analyzing alternative explanations, and communicating scientific arguments (p. 105).

A wide range of interpretations of what the phrase inquiry-based instruction means followed this publication (Flick \& Lederman, 2006; Minstrell \& van Zee, 2000; National Research Council, 2000; Windschitl, 2003). A more recent document by the U.S. National Research Council (2007), Taking Science to School: Learning and Teaching Science in Grades K-8, reviewed research on how children learn science and reconsidered how science should be taught. Recognizing that science learning is multifaceted and interrelated, this document describes science proficiency in terms of four strands, intertwined as a rope. Students who are proficient in science:

1. know, use, and interpret scientific explanations of the natural world

2. generate and evaluate scientific evidence and explanations

3. understand the nature and development of scientific knowledge; and

4. participate productively in scientific practices and discourse (p. 2)

This publication stresses that the strands are separated only for the purpose of better understanding the whole and that "students use them in concert when engaging in scientific tasks" (p. 41). The text also emphasizes there is a "complex interplay among development, learning and instruction" (p.41).

Several researchers have used these strands to guide their studies. For example, Smith, Cowan, and Culp (2009) developed a unit for kindergartners using the four strands as 
a framework for the study of seeds. Minogue, et al. (2010) examined classroom implementation of the strands. Sampson, Grooms and Enderle (2011) aligned instruments to assess scientific argumentation with aspects of science proficiency articulated in the NRC document.

In teaching my course, I had used the language of inquiry derived from the earlier National Science Education Standards (NRC, 1996). However, I decided to use the four strands of proficiencies as a framework for interpreting remarks about science learning and teaching during interviews I conducted with graduates of my course before they began teaching.

\section{RESEARCH QUESTIONS}

This study examined the following research questions:

\section{How did graduates of a science methods course envision themselves teaching sci- ence after they graduated from their teacher preparation program but before they began teaching?}

2. How did their visions of science learning and teaching align with the four strands
of science proficiency articulated by the U.S. National Research Council (2007)?

\section{METHODS}

As the instructor of the course on methods of teaching science, I used a reflective stance toward teaching (Abell \& Bryan, 1997; Darling-Hammond, 2006). A reflective stance is one that requires educators to spend time thinking and considering their instructional practices and beliefs, alone and in collaboration with others. I have studied my own teaching practices and students' learning both as a teacher (Roberts, 1999; 2000; 2007) and as a teacher educator (Roberts, 2011). Roth (2007) explained the role of teacher research as important in two ways. First, teacher research can add to the knowledge base in science education and connect the areas of practice and research. Second, such research supports the continuing professional growth of teachers and teacher educators (Hubbard \& Power 2003; Cochran-Smith and Lytle, 1999; Shulman, 2004).

As an instructor who engages in the Scholarship of Teaching and Learning (Hutchings, Huber, \& Ciccone, 2011; Hutchings \& Shulman, 1999) and self-study (Loughran \& Northfield, 1998; Schön, 1983), I believe the knowledge and understanding gained through careful investigation of my teaching practices and my students' learning will ultimately benefit my students. Moreover, as Zeichner (2007) has argued, practitioner research contributes to a broader understanding of issues related to teacher education and policy. He and others (Dana \& Yendol-Hoppey, 2009; McMillan \& Schumacher, 2010) assert the accumulation of knowledge gleaned from self-studies plays a valuable part in the way teachers envision new potentials and possibilities for engaging in inquiry-oriented teaching and learning. A case study approach was used as a research strategy, an empirical inquiry to investigate the pre-service teacher's visions of science learning and teaching within its real-life context (Yin, 2012).

\section{Setting}

I conducted this study in the context of a graduate course on methods of teaching science in a Master's certification program at an urban southwestern university in the U.S. I modeled the instructional approach recommended in the U.S. National Science Edu- 
cation Standards (National Research Council, 1996) that "Teachers of science plan an inquiry-based science program for their students" (p. 30). The textbook selected by my department also advocated this inquiry-based approach (Bass, Constant, \& Carin, 2009).

During each class session, the pre-service teachers experienced inquiry-oriented investigations that engaged them in authentic situations, some lasting several weeks, some one-time investigations. I also emphasized the intentional integration of other content areas into science, because that is what science learners and scientists do naturally, and because there is little time delegated to elementary science as a result of high stakes testing in math and reading in the U.S. (McMurrer, 2007).

\section{Participants}

In total, the sample for this study included 20 students, 17 females and three males. I analyzed the course work of 16 and interviewed seven. At the time of the interviews, all participants had completed their Master's degree but had not yet begun to teach in their own classrooms. The 16 participants consisted of three white males, eight white females, and five females from other ethnic groups (two Mexican-American, one Asian, one MidEastern, one mixed race). All of these participants had given formal consent to participate in the study. I was unable to contact the four remaining pre-service teachers, one male and three females, who were demographically similar to those who participated in the study. I, too, was a participant by virtue of engaging in practitioner research to study my own teaching practices and students' learning.

\section{Data collection}

During the course, I documented participants' assignments, weekly reflections, and multi-media portfolio finals. Assignments were evaluated for common themes with participants' comments selected to illustrate particular themes as well as for evidence of the four strands of scientific proficiency articulated in Taking Science to School: Learning and Teaching Science in Grades K-8 (NRC, 2007). A detailed analysis of the students' responses on assignments is reported elsewhere (Roberts, 2011). This report focuses upon responses during the interviews, which occurred about six months after the participants had completed the course. The pre-service teachers refer to the assignments in their interview responses. I conducted interviews with seven of these participants during the summer after they had completed my course in the previous fall and graduated from their teacher preparation program in May, but had not yet begun to teach. This was intentional, because I wanted to explore how they were looking toward their future classrooms and what their conceptions were of teaching and learning and teaching of science before they had begun their work as first time teachers. I interviewed participants in coffee shops or local restaurants around the university.

The semi-structured interviews provided the emic voice of participants (Mehra, 2002). I asked them three questions about their visions of science teaching. Although I was curious to see what connections the participants would make between the way I had taught the course and the way they would teach their future students, I phrased these questions in ways that did not explicitly ask them to make that connection.

First, I asked, "What are the characteristics of a good science teacher?" With this question, I wanted to understand what the participants believed were the important attributes of science teachers and how they envisioned themselves as teachers of science. 
Next, I asked, "Imagine that you now have a job teaching in an elementary school and you will be responsible for teaching science, what does your classroom look like and what evidence will there be that you are a teacher of science?" This question solicited information about the physical characteristics of the classroom; what did they envision a classroom would look like if teaching science occurred there? Finally, I asked, "If I walked into your classroom during science instruction, what would I see?” With this question, I sought to understand how prospective teachers thought science teaching in action would look in their rooms.

\section{Data interpretation}

I utilized several qualitative methods in interpreting the data. First, I identified common themes in the responses of the pre-service teachers based on the interviews (Thomas, 2006). I analyzed all of the data a second time to look for evidence of the strands of science proficiency. After these analyses, I conducted member checks with participants by providing them with initial interpretations of the data for their review. Respondent validation of data interpretations is central to ensuring the validity of a qualitative study (Silverman, 2001).

I believe I achieved transferability in this study according to Guba's (1981) description. Because the study is a qualitative examination of the participants' experiences in a particular context, the results may not generalize to all other science teaching contexts. Rather, I designed the study to gather data in naturally occurring phenomena to gain a better understanding of the pre-service teachers' experiences within a specific context (McMillan \& Schumacher, 2010). The goal was not to construct statements of "truth" that could be generalized to larger populations; rather, I collected and analyzed extensive data to develop detailed descriptions that allowed comparison of my particular context in the methods course to other methods courses I teach. I used multiple methods of interpretation to understand and interpret data according to the perspectives of the participants. Overlapping methods of data interpretation increases the dependability and stability of data interpretation, thereby enhancing its trustworthiness (Dana \& YendolHoppey, 2009; Guba, 1981).

\section{DESCRIPTION OF THE SCIENCE TEACHING METHODS COURSE}

I taught the methods course by modeling the pedagogy that I would hope my students would use in their own classrooms. Each week they participated in an investigation usually centered around a concept relating to the nature of science. They conducted investigations much like elementary students might. Each class discussion during and following the investigations involved them in questioning, discussing how to collect and analyze data as well as claims and evidence and possible alternative conclusions. The students' placements in elementary schools in the area provided a rich source of discussion.

There were four major assignments in the class, and these grew in complexity as the semester progressed. The first assignment challenged the students to think about science from their personal perspective, and provide me with some background information on their perceptions of science. The second assignment asked the students to explore the perspective of science of their school district and school. The third assignment asked them to evaluate a science lesson of their choice and to rewrite it using the $5 \mathrm{E}$ format 
(engage, explore, explain, elaborate, evaluate) (Bybee et al., 2006). In the fourth assignment, the students planned and implemented a lesson using a peer observer and video tape recording of their lesson, which they then used to reflect on their experience and the information from the peer observer and the videotape. Each week the students wrote a reflection. Four of the reflections had prompts I created, and the rest were free choice.

The final assignment involved creating a "snapshot" of their learning in this course by using the Carnegie KEEP TOOLkit software (now the Content Builder at merlot.org). This was a multimedia synthesis of what they thought they had learned. I encouraged them to use graphics of any kind, excerpts from their assignments and reflections, readings from the class, experiments, discussions, or experiences from their student teaching that they could use as claims and evidence of what they understood from the course. I agree wholeheartedly with Lieberman and Mace (2009), "Making multimedia representations of practice helps teachers articulate what they know (and what they need to know) and teaches the rest of us about the complexities and layered nature of teaching” (p. 87).

Although these snapshots of learning and practice varied in quality, they were an opportunity for the pre-service teachers to share their learning with peers and to give and receive critique from each other. Their representations of science teaching and learning came from their personal learning and not from an outside source. The ease of using this software made it possible for pre-service teachers to demonstrate their progress in the course, and in understanding science teaching and learning in powerful ways.

\section{FINDINGS}

This study examined how graduates of my science methods course envision themselves teaching science after they graduate from their teacher preparation program but before they begin teaching. During interviews, participants described visions of teaching demonstrating that, as they look towards their careers as elementary teachers, they also envision themselves as teachers of science. In interpreting interview data, I also considered ways in which their comments showed evidence that their visions include elements of the four strands of science proficiency articulated by the U.S. National Research Council (2007). Below I present evidence of their visions in the context of the four strands.

\section{Strand 1: Know, use, and interpret scientific explanations of the natural world}

The discussion of Strand 1 in Taking Science to School (NRC, 2007) emphasizes the identification and use of knowledge that students bring to the science classroom. If the participant accessed prior knowledge and built upon those concepts or applied knowledge to a new situation, I considered the comment to be evidence of Strand 1. In the section that follows, I have included several examples from the interviews that show evidence of Strand 1.

Participant 1 reflected during his interview, that if he were in his own classroom, he would have done the [required] lesson in a different way. His placement was in a middle school geometry class, and he tried to pick a topic that encompassed both science and math. He chose to do a lesson about tessellations and had students then create their own tessellations. In reflecting on his teaching and their learning he realized that he had missed an opportunity that would have facilitated the students' learning. He stated: 
I would first have the students look at patterns in nature. I am not sure how I would do this - maybe find some really good images, or, real things, like a honeycomb, and anyway just give them some examples and have them talk about what they see. Then we could look at some man-made kinds of tessellations, like brick walls, or chain link fences and talk about them. Why do they think they are that way-what are the advantages? I think that would have helped them before they had to create their own, because then they could apply what we had seen and discussed.

Although Participant 1 did not facilitate the connections with prior knowledge during his teaching, he recognized that it would improve the lesson and probably the learning for the students.

Participant 6 described how she would know that students understood something in this way:

When students refer back to something they have already learned, and show that they can make connections between that and something they are currently learning, I am very excited. When they can explain it to me and show it to me, or they can explain it to their friend, or when they make connections, like when they are talking to somebody and they say, "Oh yeah, it's like when we were doing that!" and then you know they are pulling from something I've previously tried to build upon and then I am like "Yes! They get it!"

These two examples are evidence of the ideas represented by Strand 1, as reported in the interviews. The participants recognized that it is important and meaningful for students to use their prior knowledge and then be able to apply it to new situations.

\section{Strand 2: Generate and evaluate scientific evidence and explanations}

I considered a comment to be evidence of Strand 2 if it involved or incorporated anything about designing and carrying out an investigation and/or evaluating claims and evidence to draw conclusions and defend them. The best example of this came from Participant 7. Building from a previous investigation, he described the ways in which he would facilitate his students' ability to design and evaluate a new investigation, and enrich their conceptual knowledge. His students had worked through a force and motion unit and each had built rubber-band propeller cars. Rather than have them add up the cost of all the parts from a list of prices, he decided to extend the lesson.

I said, "Now we're going to have a contest to see who can design the cheapest propeller car." So we were going to design in groups the cheapest propeller car that could still travel 3 feet. And so all of the kids started working, they started shaving off some of the pieces, and so some of the groups only took off like a little piece at a time to make sure it still worked. Some kids took it completely apart and then put it together as cheaply as possible. Some groups were kinda arguing with each other about [how to do] it and trying to spy on the other groups. It turned into more of a lesson they were now designing even though they had been using these cars for like a week. They were ready to take that next step and the curriculum didn't plan for 
that but by enhancing it I was able to make it mean more. This is what I want to see in science.

Participant 6 portrayed the many necessary components the students will need in order to design and analyze empirical investigations.

They would need, I would think, like, a lot of like process support before actually doing an investigation. How to organize-they would need a lot of support, step by step, everything from how you go about formulating your question to, how you actually perform the experiment, to analyzing the data, putting it into the chart. Hopefully by then they would know how to make a chart or a graph or how to analyze the data or how to record, how to methodically record, and accurately record your data and then teach them you know about independent and dependent variables, what goes on what axis. And if we're using a chart, you know, recording how many times something happens so that they would be able to have evidence. So then they'll be able to say, "Ok, now I know this because look, you can't take this away, this happened-you know, data," rather than just, "Oh, but I saw it."

Both of these examples describe scenarios of elementary students engaging in the critical thinking and work of science, through explanations of the pre-service teachers. These pre-service teachers were able to articulate ways in which investigations are meaningful and require not just process skills, but also the skills of analysis, design, discussion and the use of evidence to defend claims. This is a vision for science they have articulated here for their future classrooms.

\section{Strand 3: Understand the nature and development of scientific knowledge}

I interpreted Strand 3 in two different ways: (1) it would be considered evidence of understanding the nature and development of scientific knowledge if the participants described science as a way of knowing; or (2) if they enacted science as a way of knowing. I attributed knowledge of the nature of science to responses that indicated implicit understanding of the nature of science.

Participant 1 described an aspect of what it means to understand the nature and development of science. She stated, "I think kids need to learn about how you do science-not like they have to do it step A to Step Z, but that there are certain facets of conducting a science experiment that are important to know and important to do." Again, with an aspect of Strand 3, Participant 3 discussed being able to replicate an investigation and use multiple trials: "Maybe the answer was right but the procedure, the way they got the answer, was wrong-I would ask them to replicate it again. I would ask what would a scientist do?"

Strand 3 includes "developing a conception of 'doing science' that extends beyond experiment to include modeling, systematic observation, and historical reconstruction" (2007, NRC, p. 39). Participant 7 reflected on science with some reference to history and the need for debate in science.

Taking the idea of the Earth revolving around the sun or that the Earth is round. There was a period of time where everyone thought the Earth was 
flat, because if it weren't flat we'd all roll off, or fall off, and how do the oceans stay on? When these things were discovered, they had to convince other people. It is very important that you are able to defend your ideas in science, because if other scientists hadn't convinced us, then some discoveries would have just been thrown away and maybe not thought about for several centuries until someone else would have thought about it, and then they would have had to defend it. So defending your ideas is kind of the basis of science.

These participants showed some understanding of what it means to think and act like a scientist would, and also how to help their students understand the importance of scientific practices.

\section{Strand 4: Participate productively in scientific practices and discourse}

I considered a comment evidence for Strand 4 if it referred to discussions or to motivation and positive attitudes toward science. Creatively scaffolding discussion so that all students have a voice in the classroom community is the way Participant 2 envisioned her students participating productively in science.

I think discussion is really important; I think it's how they get a chance to learn from one another in science. Sometimes even in the same group, somebody got something different out of it, so if I am able to hear what my group member has to say - in a small group or in whole class we learn from one another. I really like to make sure that the students who are kind of shy talk up and have a chance to be heard. You might have to scaffold it that at first they just talk with their partner, and then in the small group and then when someone raises their hand to represent the group, I made a comment and I am shy, but maybe the leader of our group shared my idea with the class, I could say wow - my voice is being heard. They might even say oh so and so said this, so I think that is important. Discussion, discussion is important. You feel more like learning when you can share your ideas.

Participant 5 emphasized the idea of teamwork and echoed Participant 2's comments about students learning from one another.

They learn better that way, they learn when they talk to each other, and to challenge, and they learn when they have an assignment to do. They know they are a part of a team; they are going to accomplish something. That is important to their life and they have to start learning it in science.

Discussion is that people who know can refresh other people's mindsmaybe not only refresh but teach something to others. Some students will be able to enlighten other people's minds. Also it helps so that we can clarify any misconceptions that they have, or to bring up experiences that they have had, to engage them as well. Because one kid will say this and another will say, "oh, yeah" — so every group has a different perspective maybe about something. And then they help each other understand about it. It is more fun that way. 
Similarly, Participant 7 saw science as when students' build off of one others' ideas.

Science is definitely a social process. If I go out and do experiments on something and then I don't tell anyone about it, or when you think about stuff like the Earth revolves around the sun, I didn't have to think of that, someone else already did and shared why with the world, so now we can build off of that knowledge. Thinking more of knowledge as something that is shared socially - that's important.

Communication is key in science. The participants understood that the role of discussion is vital to student understanding, and building on conceptual knowledge. Sharing ideas and reasoning helps students share what their current understanding is, and helps teachers to identify misconceptions, and opportunities to challenge.

In interpreting the data from the interviews, I extended myself some liberty in the matching of data to the strands. One reason for this is that the strands often overlap; there are not exact delineations among them. It is often difficult to identify a statement or reference to an activity as only one particular strand. As stated in Taking Science to School: Learning and Teaching Science in Grades K-8 (NRC, 2007): "The strands are not independent or separable in the practice of science, nor in the teaching and learning of science. Rather, the strands of scientific proficiency are interwoven, and taken together, are viewed as science as practice" (p. 36-38).

\section{DISCUSSION}

This study examined the following research questions: 1) How did the participants envision themselves teaching science after they had graduated, but before they began teaching? 2) How did their visions of science learning and teaching align with the four strands of science proficiency articulated by the National Research Council (2007)?

The methods course emphasized reform-based practices, science as inquiry, culturally responsive teaching, scientific discourse, and integration of science with technology and other disciplines. Participants' writings and interview responses articulated visions of science learning and teaching including aspects of reform-based practices. Some participants intentionally incorporated and implemented reform-based strategies in field placements during the methods course and student teaching. The strands of scientific proficiency were evident in activities, assignments and participants' interviews in varying degrees.

Through the interview process, many of the participants described a professional vision that included changing the ways their students would experience science, as compared to ways in which they themselves had learned science. Some participants described changes in attitudes and beliefs that informed their visions of how they wanted science teaching and learning to occur in their own classrooms as a result of their experiences in the methods course.

Throughout the course assignments, the strands were evident but not equally in every assignment. Partly, this is due to the nature of the assignments and partly due to the way in which I interpreted the strands. Another researcher might interpret these data in different ways. The interconnectedness of the strands can make it difficult to ascribe specific criteria to each one. My results were similar to those of Minogue et al (2010) in 
that "the nature, duration, and distribution" (p. 21) of the strands varied, although the application was different.

The interviews demonstrate that participants remembered key components of reformbased ideas. They articulated visions of science learning and teaching that exemplify reform as described by the strands. Participant 7 was fortunate in that science was taught in one of his placements, although not regularly. As a result, he was able to engage the students in science learning experiences in addition to the lesson he did for the methods course. In his description of that lesson, he showed that he applied a reform-based approach to a science learning experience. This corroborates Crawford's (2007) findings that it is possible for prospective and newly qualified teachers to implement reform-based learning opportunities for their students. Anderson, Smith and Peasley (2000) suggest some students are more open to new ideas about teaching and learning, and a focused curriculum that maintains core ideas facilitates pre-service teachers' acceptance of new approaches to teaching.

Looking at data in relation to the strands of scientific proficiency, as they were evident in interviews about this methods course, has made me think more deeply about my role as a teacher educator and decisions I make as a facilitator of learning. Duschl (2008) explains that the strands of scientific proficiencies are a shift in focus for science education, moving from the "what" of science teaching to the "how and why" of science teaching. After completing this investigation, I plan to adjust the design of my science methods course to focus more explicitly on intentionally integrating the strands into the design and delivery of reform-based science instruction.

Case studies using the strands of science proficiencies (e.g., Smith, Cowan \& Culp, 2009) can offer practical models to elucidate how the strands might affect the work of prospective teachers in general. This practical model shows the strands may potentially influence the way pre-service teachers envision the future of science teaching in particular and can inform new teachers who are beginning to design their own lessons. Perhaps, if university instructors could explicitly model the use of the strands in their courses, then pre-service teachers could develop an understanding of this theoretical framework to then apply in the classroom when they begin to teach.

One caution I would offer is to not separate the strands into a checklist. School systems tend to take these checklists and use them simplistically in order to claim they are indeed being implemented. The strands of science proficiencies are complexly intertwined, and simplifying them may lead to misinterpretation. The strands also draw attention to how young children learn, and the importance of building science teaching and learning around core concepts.

Although these newly qualified teachers had not yet begun to teach, their visions of science teaching and learning describe a range of reform-based instructional approaches, like those that were modeled in their methods teaching course. These approaches to teaching and learning included having the K-8 students taking the lead in identifying the problem, generating questions, designing investigations, making and recording observations, interpreting data, creating explanations, and developing models and argument, processes similar to those articulated in the National Science Education Standards (NRC, 1996). These teachers were able to describe a promising understanding of teaching science as inquiry and claimed that they believed they would implement reform-based science practices in their new classrooms. These findings about the beliefs of new teachers are 
similar to those recorded by Crawford (2007), who noted that more research is needed on how teacher beliefs about inquiry and reform translate to practice. Bryan (2003) and Luft (2007) found there may be many different factors that influence and affect how beginning teachers' practices of teaching science will be translated into their new school site.

One thing is clear, in addition to the best approaches to teaching science, using the most current research available, we must insist in helping all teachers understand the need and the benefit to teaching science daily as part of the regular school curriculum. As science educators, we have an obligation to make public the discriminatory practices of deleting science education in some elementary schools and stand by teachers who advocate for the inclusion of science learning. Teachers are often the best change agents for reform, and can provide equal access to science for their students, and possibly influence others to do the same.

\section{LIMITATIONS}

The findings of this study are limited to the particular prospective teachers who gave permission for me to interpret their writings, including those interviewed, and myself, in one course at a particular site. Another researcher could view differently from my interpretations of ways the strands of science proficiency were related or not related to the data. Although not generalizable, the results may be useful to instructors who are teaching elementary science methods courses or to others interested in teacher education issues. To show a causal relationship between the influences of the reform-based science teaching methods course and what the participants brought to the course and their visions afterwards was not possible. However, I can see from multiple viewpoints the reflections and perceptions of the newly qualified teachers, as they looked to the future and the visions of themselves as potential teachers of science, some changes in beliefs and attitudes were evident.

\section{IMPLICATIONS}

Designing methods courses that encourage prospective teachers to challenge and refine their previous visions of science teaching is a difficult task. Important components include providing meaningful experiences in the field during methods courses, as well as providing opportunities for pre-service teachers to reflect upon and make connections between their learning throughout the course and their teaching experiences in the field. In addition, pre-service teachers need deep engagement in the practices of science, such as questioning, investigating and developing explanations based on evidence, explicitly discussing the nature of science, and providing sustained evidence to support conclusions.

The learning that occurred in the course studied here can be characterized as a part of the development of teachers' visions of science learning and teaching. These pre-service teachers remembered and envisioned particular kinds of events that can happen in classrooms and thought about these events in ways that were consistent with reform-based teaching. The fact that there was some evidence of the four strands of science proficiency in their reflections on the science methods course, and that their vision of what science learning and teaching might look like included ideas from the conceptual framework of the four strands provides evidence that at least some newly qualified teachers going into classrooms can indeed envision these practices and this framework in science learning for their students. Participants' responses to assignments indicated they were taking re- 
sponsibility for their own learning and were incorporating into their own practices aspects of the reform-based teaching that were modeled in this methods course. This implies that the teaching methods and instructional approaches employed in such a course can make a difference in prospective teachers' visions of science teaching and learning. Such visions of science learning and teaching may then inform their science teaching in elementary classrooms.

\section{FUTURE RESEARCH}

Future research must also explore the area of pre-service and newly qualified teacher visions, the sources of these visions and ways in which or if they change over time. A longitudinal study of K-8 pre-service teacher visions of teaching before and during their educational preparation, what those visions are as they leave the program, and how their visions are enacted or changed during the induction years of teaching would provide valuable information to the field.

Deborah Roberts-Harris is an assistant professor in the department of teacher education at the University of New Mexico in Albuquerque, New Mexico.

\section{REFERENCES}

Abell, S.K. (2005). University science teachers as researchers: Blurring the scholarship boundaries. Research in Science Education, 35, 281-298.

Abell, S.K., \& Bryan, L.A. (1997). Reconceptualizing the elementary science methods course using a reflection orientation. Journal of Science Teacher Education, 8(3), 153-166.

Adams, P.E., \& Krockover, G.H. (1997). Beginning science teacher cognition and its origins in the preservice secondary science teacher program. Journal of Research in Science Teaching, 34(6), 633-653.

Anderson, L.M., Smith, D.C., \& Peasley, K. (2000). Integrating learner and learning concerns: Prospective elementary science teachers' paths and progress. Teaching and Teacher Education, 16(5-6), 547-574.

Bass, J.E., Constant, T.L., \& Carin, A.A. (2009). Teaching science as inquiry. Boston: Allyn \& Bacon.

Bryan, L.A. (2003). The nestedness of beliefs: Examining a prospective elementary teacher's belief system about science teaching and learning. Journal of Research in Science Teaching, 40, 835-868.

Bybee, R., Taylor, J.A., Gardner, A., Van Scotter, P., Carlson, J., Westbrook, A., \& Landes, N. (2006). The BSCS 5E instructional model: Origins and effectiveness. Colorado Springs, CO: BSCS.

Cochran-Smith, M., \& Lytle, S. (1999). The teacher research movement: A decade later. Educational Researcher, 28(7), 15-25.

Crawford, B. (2007). Learning to teach science as inquiry in the rough and tumble of practice. Journal of Research in Science Teaching, 44(4), 613-642.

Dana, N., \& Yendol-Hoppey, D. (2009). The reflective educator's guide to classroom research $\left(2^{\text {nd }}\right.$ ed.). Thousand Oaks, CA: Corwin.

Darling-Hammond, L. (2006). Powerful teacher education. San Francisco, CA: Jossey-Bass.

Davis, E.A. (2006). Characterizing productive reflection among preservice elementary teachers: Seeing what matters. Teaching and Teacher Education, 22(3), 281-301. 
Davis, E.A., Petish, D., \& Smithey, J. (2006). Challenges new science teachers face. Review of Educational Research, 76(3), 607-651.

Duschl, R. (2008). Science education in three-part harmony: Balancing conceptual, epistemic, and social learning goals. Review of Research in Education, 32(1), 268-291.

Flick, L., \& Lederman, N. (2006). Scientific inquiry and nature of science: Implications for teaching, learning, and teacher education. New York: Springer

Guba, E.G. (1981). Criteria for the trustworthiness of naturalistic inquiries. Educational Communication and Technology, 29(2), 75-91.

Haney, J.J., Czerniak, C.M., \& Lumpe, A.T. (1996). Teacher beliefs and intentions regarding the implementation of science education reform strands. Journal of Research in Science Teaching, 33(9), 971-993.

Hubbard, R.S., \& Power, B.M. (2003). The art of classroom inquiry: A handbook for teacherresearchers (Revised ed.). Portsmouth, $\mathrm{NH}$ : Heinemann.

Hutchings, P., Huber, M., \& Ciccone, A. (2011). Scholarship of teaching and learning reconsidered: Institutional integration and impact. San Francisco: Jossey Bass.

Hutchings, P., \& Shulman, L. S. (1999). The scholarship of teaching: New elaborations, new developments. Change, 31(5), 10-15.

Jones, M.G., \& Carter, G. (2007). Science teacher attitudes and beliefs. In S. Abell \& N. Lederman (Eds.), Handbook of research on science education (pp. 1067-1104). New York: Routledge.

Kaufman, D., \& Moss, D.M. (2010). A new look at preservice teachers' conceptions of classroom management and organization: Uncovering complexity and dissonance. The Teacher Educator, 45(2), 118-136.

Lederman, N.G. (1999). Teachers' understanding of the nature of science and classroom practice: Factors that facilitate or impede the relationship. Journal of Research in Science Teaching, 36(8), 916-929.

Lieberman, A. \& Mace, D.P. (2009). Making practice public: Teacher learning in the $21^{\text {st }}$ century. Journal of Teacher Education, 61(1-2), 77-88.

Loughran, J., \& Northfield, J. (1998). A framework for the development of self-study practice. In M.L. Hamilton (Ed.), Reconceptualizing teacher practice: Self-study in teacher education (pp. 7-18). London: Falmer Press.

Luft, J. (2007). Minding the gap: Needed research on beginning/newly qualified science teachers. Journal of Research in Science Teaching, 44(4), 532-537.

Luft, J.A., \& Roehrig, G.H. (2007). Capturing science teachers' epistemological beliefs: The development of the teacher beliefs interview. Electronic Journal of Science Education, $11(2), 38-66$.

Luft, J.A., Roehrig, G.H., \& Patterson, N.C. (2003). Contrasting landscapes: A comparison of the impact of different induction programs on beginning secondary science teachers' practices, beliefs, and experiences. Journal of Research in Science Teaching, 40(1), 77-97.

McGinnis, J.R., Parker, A., \& Graeber, A. (2004). A cultural perspective of the induction of five reform-minded new specialist teachers of mathematics and science. Journal of Research in Science Teaching, 41(7), 720-747. 
McMillan, J.H., \& Schumacher, S. (2010). Research in education: Evidence-based inquiry. (7th ed.). Boston, MA: Pearson.

McMurrer, J. (2007). Choices, changes and challenges: Curriculum and instruction in the NCLB era. Washington DC: Center on Education Policy.

Mehra, B. (2002). Bias in qualitative research: Voices from an online classroom. The Qualitative Report, 7, 1. Retrieved from http://www.nova.edu/ssss/QR/QR7-1/mehra.html.

Minogue, J., Madden, L., Bedward, J., Wiebe, E., \& Carter, M. (2010). The cross-case analyses of elementary students' engagement in the strands of science proficiency. Journal of Science Teacher Education, 21, 559-587.

Minstrell, J. \& van Zee, E.H. (Eds.) (2000). Inquiring into inquiry learning and teaching in science. Washington, D.C.: American Association for the Advancement of Science.

Morrison, J.A., Raab, F., \& Ingram, D. (2009). Factors influencing elementary and secondary teachers' views on the nature of science. Journal of Research in Science Teaching, 46(4), 384-403.

National Research Council. (1996). National science education standards. Washington, DC: National Academy Press. Retrieved 5/17/2009 from http://www.nap.edu/openbook.php ?record_id=4962

National Research Council. (2000). Inquiry and the national education standards. Washington, DC: National Academy Press. Retrieved 5/17/2009 from: http://www.nap.edu/openbook .php?isbn $=0309064767$

National Research Council. (2007). Taking science to school: Learning and teaching science in grades $\mathrm{K}-8$. Washington, DC: National Academy Press.

Richardson, V. (2003). Preservice teachers' beliefs. In J. Raths \& A. R. McAninch (Eds.) Teacher beliefs and classroom performance: The impact of teacher education (pp. 1-22). Charlotte, NC: Information Age Publishing.

Roberts, D. (1999). The sky's the limit: Parents and their first grade students look at the sky. Science and Children, 37, 33-37. Reprinted in S. Koba (Ed.), Mixing it up: Integrated, interdisciplinary intriguing science in the elementary classroom. Arlington, VA: National Science Teachers Association Press.

Roberts, D. (2000). Learning to teach science through inquiry: A new teacher's story. In J. Minstrell \& E.H. van Zee (Eds.), Inquiring into inquiry learning and teaching in science (pp. 120-129). Washington, D.C.: American Association for the Advancement of Science.

Roberts, D. (2007). Learning about motion: Fun for all! In D. Roberts, C. Bove, \& E. H. van Zee (Eds.) Teacher research: Stories of learning and growing (pp. 124-136). Arlington, VA: National Science Teachers Association Press.

Roberts, D. (2011). Newly qualified teachers' visions of science learning and teaching. (doctoral dissertation). Retrieved from http://drum.lib.umd.edu//handle/1903/11631

Roth, K. (2007). Science teachers as researchers. In S. Abell \& N. Lederman (Eds.), Handbook of Research on Science Education (pp. 1203-1259). Mahwah, NJ: Lawrence Erlbaum.

Sampson, V., Grooms, J. \& Enderle, P. (2011). Instruments that can be used by researchers to assess three different aspects of science proficiency. Paper presented at Society for Re- 
search on Educational Effectiveness, Washington, DC. Retrieved from https://www.sree .org/conferences/2011f/program/downloads/abstracts/321.pdf

Schön, D. (1983). The reflective practitioner: How professionals think in action. New York: Basic Books.

Sherin, M.G., \& Han, S. (2004). Teacher learning in the context of a video club, Teaching and Teacher Education, 20(2), 163-183.

Shulman, L.S. (2004). The wisdom of practice: Essays on teaching, learning, and learning to teach. San Francisco: Jossey-Bass.

Silverman, D. (2001). Interpreting qualitative data: Methods for analyzing talk, text and interaction, $2^{\text {nd }} e d$. London, Sage.

Simmons, P.E., Emory, A., Carter, T., Coker, T., Finnegan, B., Crockett, D., Richardson, L., Yager, R., Craven, J., Tillotson, J., Brunkhorst, H., Twiest, M., Hossain, K., Gallagher, J., Duggan-Hass, D., Parker, J., Cajas,F., Alshannag, Q., McGlammery, S., Krockover, J., Adams, P., Spector, B., LaPorta, T., James, B., Reardon, K., \& Labuda, K. (1999). Beginning teachers: Beliefs and classroom actions. Journal of Research in Science Teaching, 36, 930-953.

Smith, D., Cowan, J., \& Culp, A. (2009). Growing seeds and scientists. Science and Children, 47(1), 48-51.

Thomas, D.R. (2006). A general inductive approach for analyzing qualitative evaluation data. American Journal of Evaluation, 27(2), 237-246.

Thomas, J.A., Pedersen, J.E., \& Finson, K. (2001). Validating the Draw-A-Science-Teacher-TestChecklist (DASTT-C): Exploring mental models and teacher beliefs. Journal of Science Teacher Education, 12(4), 295- 310.

Windschitl, M. (2003). Inquiry projects in science teacher education: What can investigative experiences reveal about teacher thinking and eventual classroom practice? Science Education, $87,112-143$.

Yin, R.K. (2012). Applications of case study research. Thousand Oaks, CA: Sage.

Zeichner, K. (2007). Accumulating knowledge across self-studies in teacher education. Journal of Teacher Education, 58(1), 36-46. 